Original Contribution

\title{
ENSURING THE SECURITY OF YOUTH IN THE ONLINE WORLD: THE POTENTIAL OF THE DIGITAL ART AND STEAM EDUCATION
}

\author{
V. Prezhdarova ${ }^{1}$, D. Pastarmadzhieva ${ }^{2^{*}}$ \\ ${ }^{1}$ Department of Political Science and Political Management, Institute of Social Sciences, The Russian \\ Presidential Academy of National Economy and Public Administration, Moscow, Russia \\ ${ }^{2}$ Department of Political Sciences and National Security, University of Plovdiv Paisii Hilendarski, \\ Plovdiv, Bulgaria
}

\begin{abstract}
The online world offers a huge number of opportunities and variety of information sources, which differ significantly from each other. To high extent the online world is the place, where youth spend most of their time. In such situation the creative and critical thinking are essential to help youth integrate and develop their individuality in the digital world. Furthermore, the interdisciplinary nature of digital art serves to develop creativity and critical thinking. In this way, they create new knowledge, which forms the necessary qualities for faster socialization in the virtual society. Thus, digital art merges with STEAM education, where science and art are integrated, namely Science, Technology, Engineering, Arts and Mathematics. The purpose of the current study is to identify the possible impact of STEAM education on the formation of the creative and critical thinking among young people. The authors use various methods such as analysis of the content, historical and comparative approach. The results show that the digital art and STEAM education can give the youth knowledge about how the technology is created and then express themselves through the art, which leads us to the conclusion that the indeed can support the creative and critical thinking.
\end{abstract}

Key words: youth, digital threats, digital art, STEAM education, soft power, creative thinking, critical thinking

\section{INTRODUCTION}

Today's young people are the biggest users of new technologies and their education, training, and integration into the world are accomplished through the computer (1). The digitalization process is also reflected as an important component in the innovation development strategies of the countries, such as the European Union, in The Horizon 2020 Framework Program for Research and Innovation, The Russian Federation 2020 Innovation Strategy 2020 year, Japan Society 5.0, Industry 4.0 in Germany, Digitization and Digital Economy Development Strategies, Information Security Strategies, and others that are in the base of development of both creative and criticality thinking of young people (2).

\footnotetext{
*Correspondence to: Daniela Pastarmadzhieva, Department of Political Sciences and National Security, University of Plovdiv Paisii Hilendarski, Plovdiv 4000, Bulgaria, 24 Tsar Asen Str., Plovdiv 4000,Bulgaria, +359884727096, daniela.pastarmadj ieva@gmail.com
}

In a world where big data is a leading factor on the Internet, critical thinking is the quality that will be able to indicate the addictions that the Internet generates. Once the dependencies are fixed and eliminated, young people are protected in this new environment, both for them and for their parents, and creative thinking helps them to enter the labor market in which the digital national economy is developing.

Thus, the purpose of the current study is to identify the possible impact of STEAM education on the formation of the critical thinking among young people. The object of the research is digital art and STEAM education. The focus of the research is various elements of digital art and STEAM education, which can contribute to the establishment of creative and critical thinking among youth.

This article focuses specifically on the qualities needed by a young person in the 21 st century that can be developed and protect themselves 
PREZHDAROVA $V$., et al.

with the help of digital art, which we consider to be a technology of STEAM education.

After the introductionp the paper consists of four parts. In the first are discussed the conceptual framework of the online world and the place of youth in it. It also presents the possible threats to the development of the children. The next part examines the specifics of digital art and is followed by a short overview of the new interdisciplinary educational approaches. In the concluding part is made a summary of the obtained results and the prospects for future research.

\section{YOUTH AND THE ONLINE WORLD}

From ancient times, the individuals have aimed to create their own illusory world, built of tales, legends, myths, and beliefs. They have always tried to escape from reality in other unreal worlds. The caveman, who struggled daily for survival, unwittingly accumulated experience and information that was processed subconsciously. As a result of this experience and information, they created new tools that made everyday life easier. They also shaped up because of their communication with each other within the tribe, becoming "homo sapiens". There are numerous cave artifacts such as drawings, figures that confirm their communication nature (3). However, in ancient times, communication between people was based only on a territorial basis, and nowadays it is carried out through the Internet on the computer, so communication happens not only on local but also on a global level (4). It is even more valid for the youth and children, who are born in the era of digital technology, and for some of them, it is the main way they interact with each other. (5)

To some extent, we can't even speak of online and offline worlds as areas, which are absolutely separated from each other (6). Nowadays they are interrelated and it is very hard to live without being connected in the network. This makes the youth part of an environment, which is not well examined and the consequences on their overall development. One of the rather significant risks is related to their mental health as pointed out by OECD. The latter identified that there is an increase in time, which children spend, using the internet from 21 hours per week for an average of 15 years old in 2012 to 29 hours a week in 2015 . On one hand, the online communication can support those, who have difficulties communicating face to face. However, the internet environment can foster the so called cyber-bulling and cause more risk and stress for the youth (5). According to a study on children's views on living in the digital age, the youth themselves realize the risks and sometimes even better than many adults, who were "born in a more analogue era" (7). This situation requires more involvement of the authorities in the digital environment especially as youth are concerned.

Thus, it is inevitable that the states need to protect the functioning of the new digital society that we are witnessing. For this aim, the countries adopt national strategies related to the development of various safeguards. Among the new concepts is the one related to the digital state sovereignties. In order to preserve the national identity of citizens, the role of digital national sovereignty is being strengthened, which is expressed in the appearance of censorship of content on the Internet. In different countries, censorship is implemented by various institutions, such as Roskomnadzor in Russia, the Ministry of culture in China, and others.

The Ministry of Education and Science of the Russian Federation adopted regulations, aimed at building the qualities necessary for the selfprotection of the individual in the digital environment. The most important of these qualities is critical thinking to resist new instruments of soft power (2). In the context of Russian normative documents, Voronova identifies some of the contemporary soft power tools such as:

$\checkmark \quad$ Internet memes (2, p. 212). They have the potential to divert the individual's attention so that he/she cannot concentrate in one direction. They lead to so-called clip thinking, losing people's ability to concentrate. The author even believes that memes are "virus of the mind, which is aimed at erasing the national memory and replacing it with a fashionable, popular culture". We can't agree with such generalization, but we also share the opinion that internet memes can be used intentionally to change someone's mind.

$\checkmark \quad$ Substitution of content - for example, shots taken in one place or in a certain context are replaced and set with a different meaning for the purpose of manipulating the content.

$\checkmark \quad$ Internet viruses - they are of several types: "trojans", "surrogate worms" (2, p. 210), which infect a consumer's computer and gain access to information. Thus, the leak of 
personal information of the consumer is realized.

$\checkmark \quad$ Fake news (2, p. 205) - false information that is used to form public opinion. $\checkmark \quad$ CyberSimulacra: trolls and bots (2, p. 207) - are artificially created consumers on the Internet who have programmed behavior like a real person. Their presence is important in the implementation of the protest movement to provoke participants. Today, social networks are used to organize protests, in which quickly a large number of people gather and subsequently quickly part.

Very often youth and even adults don't realize that they are exposed to such influence. Furthermore, as children and youth reactions to situations on the internet differs from the adults' "in terms of skills, risky behaviour, cognitive proficiency and risk perception and rationality" $(8$, p.65) it is hard to cover all the possible risks.

This makes it hard to teach children and youth of every threat that they may face, being in the online world and give them instructions on how to protect themselves from the threats. That is why they should acquire creative and critical thinking in order to protect themselves in whatever situation may occur. Both of them are essential in approaching everyday problems, not only on the internet. Birgili defines creative thinking as the "entire set of cognitive activities used by individuals according to a specific object, problem, and condition, or a type of effort toward a particular event and the problem based on the capacity of the individuals". Critical thinking is related mostly to the ability to consider situations from various perspectives, to have a certain dose of suspicion, to analyze and to make reasonable decisions, based on acquired knowledge. (9) Digital art and education related to it may contribute significantly to the development of creative and critical thinking.

\section{DIGITAL ART}

One of the ways to develop creative thinking is art. The current trend in art that introduces new technologies and helps integrate art, science and technology is digital art. Digital art is evolving and exists in virtual reality, which in itself denotes a phenomenon that is not a type of art or a work of art but is a medium, that is, a medium or media-exchange, which provides the stream of information.

Virtual space has functions such as:
PREZHDAROVA $V$. , et al. $\checkmark \quad$ Three-dimensionality - for example, observing the picture of a painter who paints on a flat surface from all sides, it does not change, and in the three-dimensional space of the virtual environment, the observers can choose their own point of view and change it.

$\checkmark \quad$ Interactivity and online connectivity the active involvement of the Internet user (online or offline) in the execution of actions. For example, the product is not fully finished, which implies the participation of the consumer in its development. So the user becomes a co-author.

Instance aimed at the maximum amount of senses - The viewers must lose their sense of reality in order to indulge in the new virtuality.

Digital art also forms various arts that are reproduced through computer technology. Computer-aided arts are also called digital multimedia, computer, virtual, or the art of new media. The impact of digital transforms many traditional arts such as painting, sculpture, music, the visual and other arts. In this way, young people have access to the arts of other cultures and, at the same time, have the opportunity to be a co-author or an author of their own artwork.

A piece of art is considered as digital when:

1. The artwork is software and network (internet) art.

2. Digital technologies are used as part of the reproduction process of the artwork.

3. Each artwork deals with the topic of digital technologies and their impact on society.

Historically, after the conceptual work of Marcel Duchamp's «Fountain», when art becomes a product and vice versa - the product becomes art, the roots of digital art as a form of art appear in the practice of experimental video and its continuation - video- art. Then art transforms in information and information into art. In the transition to the digital age, value is no longer determined by matter, but in the information that is stored in bits, that is, the information contains a work of art. And so this transition is brought up in the youth, for its future application in the production sphere (national economy), which is also digital. One of the trends in digital art is kinetic art. It is a moving object located in a natural environment. The Creator places mechanical objects and creates art with the help of their movements. Such is the idea of mechanical movement without human intervention, which 
PREZHDAROVA $V$. , et al.

is found in, for example, robotics. Another art influenced by digital technology is 3D animation, in which the image is managed and created in the virtual space. (10)

When the real and virtual environments are combined into a hybrid reality - mixed reality, the viewers takes an active role. They are expected to actively participate in the game, immersion, and interaction between the real and the online world. Virtual reality is focused in the fields of science, medicine and military simulacrum, and in mixing reality, different such realities are imposed on one another by a wide audience.

Mixed reality can also be created with the help of mobile phones that extend the natural boundaries of the enclosed space and give it a different look. There is widespread interest in these applications in museums, galleries, and many other cultural and educational spaces.

With the development of the hybrid environment, the boundaries between research, creativity, theory and technological practice are disappearing. Artists working with these technologies are beginning to interact interdisciplinarily with people, spaces and instruments.

On the one hand, art and technology are a means of raising the level of culture of a young person, and on the other, a way out of everyday life and entertainment, because technology serves to transition from one reality to another. That one of the likely addictions that digitalization can cause is related to new digital forms of entertainment and communication such as video games, movies, social networks and more.

The individual Internet user contributes to the construction of a new reality in which friends, news and art exist. Digital arts developing in virtual reality are characterized as interactive and by this feature, they can counteract digital dependencies because the user is familiar with how content is produced in the digital space. Knowing how this content is produced, the user can confront it. The interactive nature of digital art enables each young person to develop an individualized learning plan according to their perceptions of the digital environment.

Entertainment and technology can be used for instructional purposes as well as created by the youth themselves. In this way, the integration of young people in the world of technology of the fourth industrial revolution - 3D printer, artificial intelligence, robots, drones, the Internet of Things, autonomous car and others will be more effective and aware.

\section{STEM, STEAM, STREAM AND STEAMM EDUCATION}

The contemporary era of Industry 4.0 requires new types of professionals, who need to have various types of skills. According to the Atlas of Emerging Jobs by 2030186 professions will emerge and 57 will disappear, with emerging professions requiring STEM professionals with interdisciplinary knowledge (11). In order to match the education of the new realities of Industry 4.0, a STEM approach (Science, Technology, Engineering, and Mathematics) is introduced in education in Europe (12), which enables the learners to see the connections between the fragmented subjects they study. This creates a holistic vision for the world that increases cognitive activity and motivation to acquire knowledge of the individual.

Subsequently, the STEM approach incorporates the art and transforms into STEAM (Science, Technology, Reading, Engineering, Arts and Mathematics) (13), which develops the two brain hemispheres, incorporating convergent and divergent thinking. STEM education develops logical thinking along with the critical, while STEAM education through the arts promotes the development of intuition, creative thinking, and emotional intelligence. STEAM education is aesthetics-based learning through experience. It can be used in both formal and non-formal and informal education (14). The trend is with the increasing ability of artificial intelligence to demolish more and more jobs. Depriving a person of a profession can lead to risks for example depression, stress, suicide, etc. Therefore, the need arises for the development of emotional intelligence that is developed through STEAM education. The replacement of jobs by artificial intelligence will make qualities such as empathy and emotional intelligence increasingly necessary for human integration in the new automated digital society.

Concepts are also emerging for STREAM education (Science, Technology, Reading, Engineering, Arts and Mathematics), which includes language and writing and STEAMM education (Science, Technology, Engineering, 
Arts, Mathematics and Music) with extensive learning of music, but STEAM education is the most widespread.

This new teaching methodology is increasingly entering the educational system of countries around the world and replacing old educational programs that are becoming increasingly inadequate to digital reality. His hierarchical and mass character makes it ineffective in education for building the necessary qualities of the 21 st century. (15)

In addition, these new trends are embedded in a new line of art called "art-technologyscience" (16). In it, the artist, who may be a teacher, enters the laboratory and experimentally shows his work of art, through which the contemporary viewer becomes a coauthor, who is a learner because he/she receives informal experience from his participation, learning new things.

In the new art direction, there are "science-arttechnology" together, not as fragmented, eclectic, nihilistic parts of different cultures of postmodernism. This simultaneous existence of all parts is evidence of the emergence of a new cultural era after Postmodernism (17).

\section{CONCLUSION}

The Syncretism of antiquity has also had an interactive character, like contemporary art, science, and education. In the modern world, there is similar syncretism, but unlike the environment is changing - from real it is becoming digital. However, as the nation states start to make efforts in order to create their digital sovereignty the syncretism may transform again into fragmentation.

Current interactivity is a tendency for students to enter research laboratories to experiment and create their own digital works of art, which they then present as exhibitions, promotions, performances, happenings or installations.

The development of the new cultural era is enshrined in the national innovation development strategies of many countries, but especially in the USA, the European Union, Russia as part of the Eurasian Economic Union and BRICS, Japan, and other developed countries in the world.

In fact, young people play a major role in the development and implementation of strategies for future innovation development for the construction of the new cultural age, and
PREZHDAROVA V., et al.

critical and creative thinking are the two most important qualities that will allow them to adequately fit into the digital reality. Through STEAM education children can simultaneously observe and get acquainted with the way the technology is being made and after that implement this technology in practice to express themselves through art. Such wide knowledge allows the youth to understand deeply the functioning of the digital world and to identify the correlations between their activities on the internet and the consequences that may follow. Such education in practice leads to the development of children's two brain hemispheres, which helps them to understand and better analyze the situations so that they won't need a comprehensive list of the threats on the Internet in order to protect themselves.

However, the current study is just a starting point for the examination of the correlation between the STEAM education and the development of such creative and critical thinking, which are expected to protect the youth in the online world. It is a topic, which examination must go further.

\section{REFERENCES}

1. Soldatova G. U., Rasskazova E. I., Nestik T. A. Tsifrovoe pokolenie Rossii: kompetentnost' i bezopasnost' [The digital generation of Russia: competence and security] Smysl, Moscow, pp 6, 2017. (In Russian)

2. Voronova O. Informacionnopsihologicheskaya bezopasnost' Rossii v usloviyah novyh global'nyh ugroz: monografiya. [Information and psychological security of Russia in the context of new global threats: monography], Aspect Press, Moscow, pp 205-212, 2019. (In Russian)

3. Harari. Y. N. Sapiens: A Brief History of Humankind. Sinbad, Moscow, pp. 6-36, 2016. (In Russian)

4. Hu, C., Kumar, S., Huang, J., \& Ratnavelu, $\mathrm{K}$. The expression of the true self in the online world: a literature review. Behaviour \& Information Technology, 1-11, 2019

5. OECD. Children \& Young People's Mental Health in the Digital Age. Shaping the Future. 2018.

6. Gloviczki, P. J. Journalism and Memorialization in the Age of Social Media, Palgrave Macmillan, New York, USA, 2015. 
7. UNICEF. Young and Online: Children's perspectives on life in the digital age, 2017.

8. Staksurd, E. Children in the online world. Risk, regulation, rights., Ashgate Publishing limited, Farnham, England, 2013.

9. Birgili, B. Creative and Critical Thinking Skills in Problem-based Learning Environments, Journal of Gifted Education and Creativity, 2(2), pp. 71-80, 2015

10.Farting S., Cork R., Art: The Whole History. Knigomania, Sofia, 2013. (In Bulgarian)

11.Atlas of Emerging Jobs, http://atlas100.ru/en/

12.Nistor, A., Gras-Velazquez, A., Billon, N. \& Mihai, G. Science, Technology, Engineering and Mathematics Education Practices in Europe. Scientix Observatory report. December 2018, European Schoolnet, Brussels, 2018.

13. Haesen, S. and Put, E. STEAM Education in Europe: A Comparative Analysis Report, 2018.

14.Klipova N., STREAM Approach in a training project. Sovremennoe obrazovanie: Sovremennoe obrazovanie: Aktual nye
PREZHDAROVA V., et al. voprosy, dostizheniya i inovacii: sbornik statey XXVII Mezhdunarodnoy nauchno prakticheskoy konferencii. Penza: MCNS Nauka I Prosveshchenie. [Science and Education. Modern Education: Current issues, achievement and innovations: collection of articles ofthe XXVII International scientific conference] International centre for scientific cooperation. p 172, 2019.(In Russian)

15.Anisimova, T. I., Shatunova, O. V., Sabirova, F. M., STEAM-Education as Innovative Technology for Industry 4.0. Nauchnyy dialog, 11, pp 322-332, 2018. (In Russian)

16. Ivanova C., Neuroaesthetics of emotion and contemporary art forms // $\mathrm{PhD}$ Thesis in Art Psychology (overview), pp 1 - 4. 2017. https://www.academia.edu/37223135/PhD_T hesis_NEUROAESTHETICS_OF_EMOTIO N_AND_CONTEMPORARY_ART_FORM_ overview_.pdf?fbclid=IwAR2z7nOh_v_pe00 wECCLTRgXjvXcHdKH5yBVg5io4Y1kijvcQ9Q-TcHrrQ

17.Toth J. The Passing of Postmodernism. A Spectroanalysis of the Contemporary, State University of New York Press, Albany, pp. $5-10,2010$ 